\title{
Strategic communication as discursive institutional work: a critical discourse analysis of Mark Zuckerberg's legitimacy talk at the European Parliament
}

\author{
Lischka, Juliane A
}

\begin{abstract}
Digital platforms are under public scrutiny and face a negotiation process regarding their social responsibility. In this institutional discourse about moral responsibilities, corporate actors aim at defending the legitimacy of digital platforms. This study conceptualizes strategic communication as a means for conveying conformity to legitimacy expectations, to shape legitimacy judgements, and to discursively conduct institutional work. A critical discourse analysis of Zuckerberg's testimony before the EU Parliament finds that prag-matic, moral, and cognitive legitimacy is signaled through corporate ability, responsibility, and conformity narratives, respectively. Moreover, Zuckerberg's techno-libertarian talk advocates Silicon Valley ideology through utility narratives of artificial intelligence. Thus, Zuckerberg conducts institutional work as an institutional entrepreneur whose strategic communication seeks to manipulate views as well as institutions.
\end{abstract}

DOI: https://doi.org/10.1080/1553118X.2019.1613661

Posted at the Zurich Open Repository and Archive, University of Zurich ZORA URL: https://doi.org/10.5167/uzh-170820

Journal Article

Accepted Version

Originally published at:

Lischka, Juliane A (2019). Strategic communication as discursive institutional work: a critical discourse analysis of Mark Zuckerberg's legitimacy talk at the European Parliament. International Journal of Strategic Communication, 13(3):197-213.

DOI: https://doi.org/10.1080/1553118X.2019.1613661 
This is an Accepted Manuscript of an article published by Taylor \& Francis in International Journal of Strategic Communication, available online:

Lischka, J. A. (2019). Strategic Communication as Discursive Institutional Work: A Critical Discourse Analysis of Mark Zuckerberg's Legitimacy Talk at the European Parliament. International Journal of Strategic Communication. Advance online publication. https://doi.org/10.1080/1553118X.2019.1613661

\title{
Strategic Communication as Discursive Institutional Work
}

\section{A Critical Discourse Analysis of Mark Zuckerberg's Legitimacy Talk at the Euro- pean Parliament}

Juliane A. Lischka

Department of Communication and Media Research, University of Zurich

\begin{abstract}
Digital platforms are under public scrutiny and face a negotiation process regarding their social responsibility. In this institutional discourse about moral responsibilities, corporate actors aim at defending the legitimacy of digital platforms. This study conceptualizes strategic communication as a means for conveying conformity to legitimacy expectations, to shape legitimacy judgements, and to discursively conduct institutional work. A critical discourse analysis of Zuckerberg's testimony before the EU Parliament finds that pragmatic, moral, and cognitive legitimacy is signaled through corporate ability, responsibility, and conformity narratives, respectively. Moreover, Zuckerberg's techno-libertarian talk advocates Silicon Valley ideology through utility narratives of artificial intelligence. Thus, Zuckerberg conducts institutional work as an institutional entrepreneur whose strategic communication seeks to manipulate views as well as institutions.
\end{abstract}

Keywords: corporate communications, corporate legitimacy, corporate social responsibility (CSR), digital platforms, Facebook, institutional work 
This is an Accepted Manuscript of an article published by Taylor \& Francis in International Journal of Strategic Communication, available online:

Lischka, J. A. (2019). Strategic Communication as Discursive Institutional Work: A Critical Discourse Analysis of Mark Zuckerberg's Legitimacy Talk at the European Parliament. International Journal of Strategic Communication. Advance online publication. https://doi.org/10.1080/1553118X.2019.1613661

\section{Introduction}

Digital platforms such Facebook, Twitter, Google, and YouTube have become powerful curators and instruments of online communication on a global scale. While globally acting businesses are specifically expected to behave socially and politically responsible (Scherer \& Palazzo, 2011), there is a growing consensus that digital platforms have negative implications for democracies through their enabling of information distribution that influences political opinions and elections (e.g., Bannister \& Connolly, 2018; Healey \& Woods, 2017). Especially Facebook is under public scrutiny and faces a negotiation process regarding its social responsibilities stemming from the Cambridge Analytica scandal in March 2018. This scandal, which was related to a misuse of personal user data without consent, is accompanied by a public discussion of the social responsibilities of digital platforms. The scandal was also the initiator of hearings on Facebook in the U.S. Senate and the European Parliament. Despite the significant role of digital platforms in global communications and the growing attention to their social responsibilities, "a radical reassessment of [Google's and Facebook's] roles in society is overdue, and with it an appreciation of the responsibilities that accompany the power that they have acquired." (Naughton, 2018, p. 389).

This study aims at explaining how Facebook strategically negotiates its social responsibilities. While neo-institutional theory suggests that external legitimacy expectations function as conformity constraints for company behavior, suggesting that digital platforms broadly act in accordance to social responsibility expectations, discursive institutionalism argues that external expectations are socially constructed. The latter involves the evaluand as strategic communicator who potentially affects social expectations. Building on both institutionalist theories, this study uses critical discourse analysis to investigate the strategic defense narratives and their discursive functions that Facebook's founder and CEO Mark 
This is an Accepted Manuscript of an article published by Taylor \& Francis in International Journal of Strategic Communication, available online:

Lischka, J. A. (2019). Strategic Communication as Discursive Institutional Work: A Critical Discourse Analysis of Mark Zuckerberg's Legitimacy Talk at the European Parliament. International Journal of Strategic Communication. Advance online publication. https://doi.org/10.1080/1553118X.2019.1613661

Zuckerberg spoke about in his testimony before the European Parliament in May 2018. It conceptualizes the testimony as a form of strategic corporate social responsibility (CSR) communication that strives at influencing legitimacy judgments of Facebook and is an attempt at institutional work.

\section{Theoretical Framework}

\section{Legitimacy Expectations as Isomorphic Constraints}

According to Meyer and Rowan (1977), institutions are considered as exogenous constraints for company behavior and explain isomorphic conduct across companies. In this sense, companies are regarded as results of complying with external expectations by aligning their conduct to norms and standards (DiMaggio \& Powell, 1983; Meyer \& Rowan, 1977; Zucker, 1987). Companies consider norms and standards because they are embedded in a political and economic environment that addresses these expectations (Campbell, 2007; Waddock, 2008). Otherwise, organizations lose their legitimacy and "reservoir of support" (Tost, 2011, p. 686), which is vital for their survival (Ashforth \& Gibbs, 1990).

To behave in a legitimate manner can thus be conceptualized as an isomorphic constraint for companies. Corporate legitimacy is defined as "a generalized perception or assumption that the actions of an entity are desirable, proper, or appropriate within some socially constructed system of norms" (Suchman, 1995, p. 574). This definition supports Meyer and Rowan's (1977) concept that social expectations on a macro level determine how companies ought to operate, providing legitimacy when they conform (Alvesson, Hallett, \& Spicer, 2019, p. 120). In order to be perceived as legitimate, a company must adapt to expectations of external parties. External parties function as a company's legitimacy judges, such as consumers and suppliers as well as so-called validation institutions such as regulators 
This is an Accepted Manuscript of an article published by Taylor \& Francis in International Journal of Strategic Communication, available online:

Lischka, J. A. (2019). Strategic Communication as Discursive Institutional Work: A Critical Discourse Analysis of Mark Zuckerberg's Legitimacy Talk at the European Parliament. International Journal of Strategic Communication. Advance online publication. https://doi.org/10.1080/1553118X.2019.1613661

and the news media (Bitektine \& Haack, 2015). Bitektine and Haack (2015) state that corporate legitimacy is an assessment by individual judges on a micro level that is constructed from direct perceptions of company behavior, perceptions of the legitimacy that validation institutions ascribe to a company, and the perception of a collective legitimacy judgment. Thus, corporate legitimacy is a complex social judgment nurtured by various legitimacy cues. CSR provides cues for judging corporate legitimacy (Johansen \& Ellerup Nielsen, 2011; Lock \& Schulz-Kappe, 2019). CSR can be conceptualized as a company’s capacity to respond to moralistic, social pressures (Vallentin, 2007) and represents a set of norms that is central to a perception of companies being desirable and appropriate. The widely homogenous adaption of companies to social responsibilities suggests that such expectations represent isomorphic constraints (Campbell, 2007). According to Carroll's (1991) set of four hierarchical corporate social responsibilities, companies are expected to conform to business, legal, ethical, and philanthropic standards. While operating profitably and obeying the law comprise rather essential requirements for enduring as a company, the latter two dimensions are less obligatory. Ethical responsibility, i.e., to do what is just and fair and to avoid harm, is described as expected and a philanthropic responsibility, i.e., to be a good citizen as desired by society (Carroll, 1991). Carroll's responsibilities represent the implementation of social expectations in company behavior. That is, corporate social responsibility behavior is the result of adapting to external expectations. Yet since corporate legitimacy is the judgement of company behavior by external parties, credibly fulfilling social responsibilities grants corporate legitimacy (Lock \& Schulz-Kappe, 2019).

Suchman (1995) differentiates three co-existing legitimacy dimensions: pragmatic, moral, and cognitive. First, pragmatic legitimacy is ascribed to a company when the company's most immediate audiences perceive that they receive benefits from the company's 
This is an Accepted Manuscript of an article published by Taylor \& Francis in International Journal of Strategic Communication, available online:

Lischka, J. A. (2019). Strategic Communication as Discursive Institutional Work: A Critical Discourse Analysis of Mark Zuckerberg's Legitimacy Talk at the European Parliament. International Journal of Strategic Communication. Advance online publication. https://doi.org/10.1080/1553118X.2019.1613661

actions and believe the company responds to their interests. This form of legitimacy refers to the match between self-interests of individuals and company conduct, transforming the role of audiences into utility-expecting constituencies (Suchman, 1995, p. 578). Shareholders may expect a company to be merely profitable, which is an essential business responsibility according to Carroll (1991). In contrast, consumers may expect to purchase a useful product that was produced under fair conditions, which falls under moral responsibilities. Regulators may consider companies that are good citizens as highly legitimate. That is, pragmatic legitimacy depends on specific expectations of roles by legitimacy judges and can be nurtured from various dimensions of Carroll's (1991) corporate responsibility.

Suchman's (1995) second dimension of moral legitimacy is primarily related to Carroll's ethical and philanthropic responsibilities. Moral legitimacy is a socially constructed judgment of ethical company behavior, i.e., "the right thing to do" (Suchman, 1995, p. 579). If a company acts ethically and philanthropically responsible, it may be judged as morally legitimate. But a company can also lose moral legitimacy if it breaks business or legal rules due to immoral reasons, i.e., not doing everything to avoid harm or not behaving as a good citizen. This relates also to Carroll's business and legal responsibilities. Castelló and Lozano (2011, p. 14) argue that moral legitimacy becomes more important in global societies and is needed to comply with new sustainability expectations among stakeholders.

The third form of legitimacy may represent a subtle and powerful legitimacy status at the same time (Suchman, 1995, p. 583): Cognitive legitimacy emerges "if acceptance is based on some broadly shared taken-for-granted assumptions" (Palazzo \& Scherer, 2006, p. 72), indicating that any deviation from the status quo is unthinkable. The status of cognitive legitimacy may be reached if a company steadily acts in line with social expectations, indicating that isomorphic adaptation grants cognitive legitimacy (Scherer, Palazzo, \& Seidl, 
This is an Accepted Manuscript of an article published by Taylor \& Francis in International Journal of Strategic Communication, available online:

Lischka, J. A. (2019). Strategic Communication as Discursive Institutional Work: A Critical Discourse Analysis of Mark Zuckerberg's Legitimacy Talk at the European Parliament. International Journal of Strategic Communication. Advance online publication. https://doi.org/10.1080/1553118X.2019.1613661

2013). Technologies or policies may gain a taken-for-granted status, but true cognitive legitimacy may hardly be reached by a company, according to Suchman (1995).

A company can move from pragmatic to moral and to cognitive legitimacy, suggesting a hierarchical relation between these dimensions (Suchman, 1995). Yet, while pragmatic and moral legitimacy is based on discursive evaluation, cognitive legitimacy relates to unspoken assumptions (Suchman, 1995, p. 585). Figure 1 portrays corporate legitimacy as a threedimensional, hierarchical social judgment being nurtured by CSR signals and taking institutional legitimacy expectations of society on a macro level into consideration. When legitimacy expectations on a macro level function as isomorphic constraints, companies adapt to these expectations (conformation strategy).

\section{Legitimacy Expectations as a Product of Corporate Manipulation}

Corporate legitimacy as a product of discursive institutional work. Legitimacy is a judgment that is based on perceptions of companies' observable properties and behaviors (Bitektine \& Haack, 2015). Moreover, legitimacy judges select the social norms on which they judge the legitimacy of a company (Bitektine \& Haack, 2015). This allows a corporate evaluand to behave strategically to manipulate their legitimacy categories and perceptions. To be perceived as legitimate, companies can present themselves as conforming to existing institutional expectations as well as manipulate those institutional expectations (Scherer et al., 2013; Suchman, 1995). Scherer et al. (2013) suggest that companies favor manipulation over conformation when the costs of corporate change are high. Suchman (1995) indicates that manipulation is specifically relevant for innovators who must actively promote new institutions, i.e., they become institutional entrepreneurs. 
This is an Accepted Manuscript of an article published by Taylor \& Francis in International Journal of Strategic Communication, available online:

Lischka, J. A. (2019). Strategic Communication as Discursive Institutional Work: A Critical Discourse Analysis of Mark Zuckerberg's Legitimacy Talk at the European Parliament. International Journal of Strategic Communication. Advance online publication. https://doi.org/10.1080/1553118X.2019.1613661

The idea to actively change institutions is central in the discursive turn of institutionalism, where institutions are not merely regarded as external constraints for company behavior but as negotiable by all parties concerned. That is, corporate actors can participate in the social process of constructing institutions. In this way, institutions are described as social constructs resulting from a social process in which external and corporate actors are discursively involved (Kostova, Roth, \& Dacin, 2008). In this negotiation process, communication is key, understood as dialogic interaction between the public, the media, and political and corporate actors (Schmidt, 2008, p. 310). Hence, "all institutions are discursive products" (Phillips, Lawrence, \& Hardy, 2004, p. 638) resulting from communicative struggles between actors who push to change or maintain a practice (Clemente \& Roulet, 2015). That is, through discourse, institutions can be strengthened, renewed, altered, or disposed.

Corporate actors who actively change institutions according to their interests represent institutional entrepreneurs (DiMaggio, 1988; Maguire, Hardy, \& Lawrence, 2004). In institutional entrepreneurialism, actors work to influence institutions by lobbying, for instance, for regulatory change. The attempt to influence institutions is conceptualized as institutional work, that is, "the purposive action of individuals and organizations aimed at creating, maintaining and disrupting institutions" (Lawrence \& Suddaby, 2006, p. 215). Related to the idea that institutions are discursively constructed, the work of institutional entrepreneurs is discursive in nature (Maguire \& Hardy, 2016). Highlighting the role of communication, Maguire and Hardy (2016, p. 8) conceptualize institutional entrepreneurs as "authors of texts" that structure institutional discourse.

Lawrence and Suddaby (2006) identify various forms of discursive institutional work that result in institutional innovation, maintenance, and disruption. Advocacy, for instance, creates new institutions by using suasion to mobilize political and regulatory support. In 
This is an Accepted Manuscript of an article published by Taylor \& Francis in International Journal of Strategic Communication, available online:

Lischka, J. A. (2019). Strategic Communication as Discursive Institutional Work: A Critical Discourse Analysis of Mark Zuckerberg's Legitimacy Talk at the European Parliament. International Journal of Strategic Communication. Advance online publication. https://doi.org/10.1080/1553118X.2019.1613661

contrast, mythologizing maintains existing institutions by creating and sustaining stories regarding an institution's past. Actors disrupt institutions by reconfiguring or problematizing the boundaries that constitute them (Lawrence \& Suddaby, 2006, p. 138). Institutional work thus attempts to discursively shape institutions, potentially including corporate legitimacy categories.

The opportunity to discursively manipulate legitimacy expectations and legitimacy judgments is illustrated in Figure 1 (manipulation strategy). The implementation of institutional work can be conceptualized as strategic communication in which specific communication strategies are applied for each of Suchman's legitimacy dimensions, as described in the next section.

[Figure 1 about here]

Signaling legitimacy through strategic communication. Corporate communication comprises symbolic activities aimed at creating favorable views among stakeholders a company depends on (van Riel \& Fombrun, 2007) and thus provides argumentation that separates the organization from an illegitimate status (Ashforth \& Gibbs, 1990; Suchman, 1995). Strategic corporate communication comprises all communication "that is substantial for the survival and sustained success" (Zerfass, Verčič, Nothhaft, \& Werder, 2018, p. 493) of a company. Communication signaling corporate legitimacy can be classified as strategically significant for the company goals. While signaling conformity with legitimacy expectations through strategic communication, companies may also use communication strategically to shape legitimacy expectations and their legitimacy image. As described in the previous section, these manipulation attempts comprise discursive institutional work. With strategic communication, companies attempt to discursively shape their legitimacy image as well as the categories on which their legitimacy will be judged (Palazzo \& Scherer, 2006; Scherer 
This is an Accepted Manuscript of an article published by Taylor \& Francis in International Journal of Strategic Communication, available online:

Lischka, J. A. (2019). Strategic Communication as Discursive Institutional Work: A Critical Discourse Analysis of Mark Zuckerberg's Legitimacy Talk at the European Parliament. International Journal of Strategic Communication. Advance online publication. https://doi.org/10.1080/1553118X.2019.1613661

et al., 2013). Thus, discursive institutional work can be recognized as a feature of strategic communication.

Various communication strategies have been identified for communicating corporate legitimacy or legitimizing decisions (Kim \& Rader, 2010; Scherer et al., 2013; Suchman, 1995; van Leeuwen \& Wodak, 1999). Each of these strategies can be assigned to one legitimacy dimension. First, pragmatic legitimacy is signaled through responding to audience demands (Suchman, 1995) and can be conveyed by a corporate ability-focused communication strategy as suggested by Kim and Rader (2010), who define corporate ability as a company's expertise in producing high-quality products or services. Corporate communication that triggers product-related associations and consumption benefits can contribute to the pragmatic legitimacy of a company. This relates to instrumental rationalization by focusing on the utilities and positive externalities of products or services, identified by van Leeuwen and Wodak (1999) as one of four discursive legitimization strategies. That is, an ability-focused strategy may use instrumental rationalization to argue pragmatic legitimacy. Further, storytelling about the founding myth or company history, i.e., mythopoesis (van Leeuwen \& Wodak, 1999), indicates corporate ability. Lawrence and Suddaby (2006) describe the method of mythologizing to maintain the status quo of an institution. Secondly, moral legitimacy can be signaled through moral reasoning (Scherer et al., 2013) and conforming to ideals (Suchman, 1995). Social-responsibility talk suggests that the company is a good member of society regarding social, environmental, and political issues (Kim \& Rader, 2010, p. 63), referring to ethical and philanthropic responsibilities (Carroll, 1991). Regarding the legitimization of decisions, van Leeuwen and Wodak (1999) identify moral evaluation through referencing values such as well-being, leadership, public interest, and security. Regarding values, Suchman (1995) suggests referring to success stories, for instance technical success, since success 
This is an Accepted Manuscript of an article published by Taylor \& Francis in International Journal of Strategic Communication, available online:

Lischka, J. A. (2019). Strategic Communication as Discursive Institutional Work: A Critical Discourse Analysis of Mark Zuckerberg's Legitimacy Talk at the European Parliament. International Journal of Strategic Communication. Advance online publication. https://doi.org/10.1080/1553118X.2019.1613661

preludes moral value. In order to repair moral legitimacy, companies need to explain their mistakes and revise their practices (Suchman, 1995). Third, for cognitive legitimacy, companies need to conform to external expectations (Scherer et al., 2013; Suchman, 1995). For instance, companies need to formalize and professionalize their operations to meet the interests and concerns of their most powerful interest groups (Scherer et al., 2013). Moreover, companies can conduct institutional work through popularizing new models, which represents a cognitive legitimation strategy (Suchman, 1995). The implication of conformity can be achieved through references to authorities such as the law, industry standards, common sense, or specific individuals, i.e., authorization (van Leeuwen \& Wodak, 1999). On the one hand, actors "borrow" the legitimacy of other entities and attempt to convey it to their issues. On the other hand, actors illustrate that they are conforming to expectations of external authorities. In general, such communication strategies have to be perceived as credible in order to positively affect legitimacy (Lock \& Schulz-Kappe, 2019). Table 1 summarizes the discursive legitimation strategies per legitimacy dimension.

[Table 1 about here]

\section{Digital Platforms and Their Legitimacy Crisis}

Digital platforms are defined based on their application of digital technology on twosided markets of users and suppliers and are sub-classified by their revenue model. Digital platforms use "digital technology as an interface between the users or consumers of a product or service and its suppliers" (Coyle, 2018, p. 50). Advertising-funded platforms such as Google, Facebook, YouTube, and Twitter represent one subcategory of digital platforms in which users access content produced by suppliers and can produce content themselves. The 
This is an Accepted Manuscript of an article published by Taylor \& Francis in International Journal of Strategic Communication, available online:

Lischka, J. A. (2019). Strategic Communication as Discursive Institutional Work: A Critical Discourse Analysis of Mark Zuckerberg's Legitimacy Talk at the European Parliament. International Journal of Strategic Communication. Advance online publication. https://doi.org/10.1080/1553118X.2019.1613661

revenue model of these advertising-funded platforms is based on the bundling of user attention to which advertising can be targeted and thus on harvesting human attention for commodification (Wu, 2016).

The conduct of digital platforms is often described as purely revenue-driven and lacking ethical responsibility. Facebook, for instance, is portrayed as "an algorithm-driven advertising company governed solely by profit imperatives" (Pickard, 2017, para 4) that views users as "targets of data extraction" (Zuboff, 2015, p. 86). This focus on business logics is identified as "surveillance capitalism" (Zuboff, 2015), viewing platforms as economic actors that react to business responsibilities instead of considering social responsibilities.

Besides revenue orientation, the logics of digital platforms are found to include the belief in the ubiquitous capacity of technology. Healey and Woods (2017) describe such techno-utopian views as part of the Silicon Valley ideology. This includes the assumption that information should be free because "the pathway to personal happiness and social wellbeing is the collection and distribution of information" (Healey \& Woods, 2017, p. 3). Russell (2017) argues that such technology logics build an institutional force embracing the belief that every problem can be solved with digital technology and that technology serves society. As a result, humans "naively believe that for most personal and social needs there must be largely technological solutions" (Schultze, 2004, p. 19), and Silicon Valley technology elites advocate and defend this view (Healey \& Woods, 2017).

Generally, digital platforms' products and services bear positive as well as negative externalities for societies. Positive externalities are generated through encouraging engagement in public debate and politics, for instance. However, digital platforms also generate negative externalities based on the same conduct, such as the distribution of disinformation, 
This is an Accepted Manuscript of an article published by Taylor \& Francis in International Journal of Strategic Communication, available online:

Lischka, J. A. (2019). Strategic Communication as Discursive Institutional Work: A Critical Discourse Analysis of Mark Zuckerberg's Legitimacy Talk at the European Parliament. International Journal of Strategic Communication. Advance online publication. https://doi.org/10.1080/1553118X.2019.1613661

which negatively affects the public sphere. Being systemic intermediaries for communication, digital platforms have initially, unintendedly gained power over the public sphere, which platforms now intentionally use to generate revenue by offering access to users whose viewpoints can potentially be changed (Naughton, 2018). With such great power comes great responsibility. However, it has been argued that digital platforms widely ignore their responsibilities to society (Taddeo \& Floridi, 2016; Tan \& Tan, 2012) and that social responsibility is not part of platform logics (Napoli \& Caplan, 2017; Russell, 2017). That socially responsible behavior is not in balance with expectations becomes visible in public debate, in which the moral legitimacy of platforms is questioned. According to Taddeo and Floridi (2016), much discussed negative externalities of digital platforms are the biasing of public debate, censorship, harmful content, and freedom of speech, as well as user privacy protection and data access consent.

The negative consequences of digital platforms' products and services for its users, as well as society and the public debate about it, indicate a product and service crisis on an end level. According to Jong and van der Meer (2017), corporate social responsibility for products and services means that a company uses its products and services to do good. The end level involves objectives related to products and services "such as consumer health in the case of the dairy firm, and the creation of entrepreneurial opportunities in the case of the bank" (Jong \& van der Meer, 2017, p. 78), or the provision of a public sphere that fosters unbiased information distribution in the case of digital platforms. That is, digital platforms face a product-harm crisis that is defined as "well-publicized occurrences wherein products are found to be defective or dangerous" (Dawar \& Pillutla, 2010, p. 215). Yet, in the Cambridge Analytical scandal, a third party was involved using Facebook as a platform to collect user data, which indicates aspects of a supplier crisis. A socially responsible company is 
This is an Accepted Manuscript of an article published by Taylor \& Francis in International Journal of Strategic Communication, available online:

Lischka, J. A. (2019). Strategic Communication as Discursive Institutional Work: A Critical Discourse Analysis of Mark Zuckerberg's Legitimacy Talk at the European Parliament. International Journal of Strategic Communication. Advance online publication. https://doi.org/10.1080/1553118X.2019.1613661

"actively urging its suppliers to also become sustainable or socially responsible" (Jong \& van der Meer, 2017, p. 79), which Facebook did not. Although it was a third party that acted socially irresponsibly, Facebook can be ascribed responsibility for the behavior of the third party. Thus, the Cambridge Analytica scandal can be defined as a supplier-caused productharm crisis.

In such crises, product-related corporate ability and social responsibility intertwine. Building on Kim and Rader (2010), corporate ability of digital platforms can be defined as the ability and expertise to produce high-quality products or services that minimize negative externalities for users and democratic societies, which is fundamental to regarding digital platforms as good members of society and thus to ascribing social responsibility. This indicates that pragmatic and moral legitimacy are closely related in the digital platforms' product-harm crisis.

The product-harm crisis becomes evident in public debate in which digital platforms take part as well. In a product-harm crisis, the social responsibility-focused communication strategy of a company is found to be beneficial in offsetting damages to corporate legitimacy (Kim, 2014). Moreover, a defensive reasoning strategy can convince external audiences to attribute less blame to the company (Tao, 2016). Regarding the role of digital platforms in this public negotiating process, Gillespie (2010) states that platforms' corporate communication goes beyond ability and responsibility strategies and embraces institutional work. He concludes that platforms communicate "strategically, to position themselves both to pursue current and future profits, to strike a regulatory sweet spot between legislative protections that benefit them and obligations that do not" as well as work "not just politically but also discursively to frame their services and technologies" (Gillespie, 2010, p. 348). Discursively, 
This is an Accepted Manuscript of an article published by Taylor \& Francis in International Journal of Strategic Communication, available online:

Lischka, J. A. (2019). Strategic Communication as Discursive Institutional Work: A Critical Discourse Analysis of Mark Zuckerberg's Legitimacy Talk at the European Parliament. International Journal of Strategic Communication. Advance online publication. https://doi.org/10.1080/1553118X.2019.1613661

digital platforms have managed to position themselves "as champions of freedom of expression" while they downplay their roles in public communication "as merely an intermediary, to limit [their] liability for the users' activity" (Gillespie, 2010, p. 356).

Against the background of the public negotiation processes of Facebook's social responsibility, we ask the following about Facebook's corporate communication.

RQ 1. What discursive strategies does Facebook pursue to defend its pragmatic, moral, and cognitive legitimacy?

RQ 2. In what way can characteristics of institutional work be identified in Facebook's discursive strategies?

\section{Method}

\section{Critical Discourse Analysis (CDA)}

Public discourses occur within wider processes of social and cultural change, power relations, and ideology (Fairclough, 1995). Discourse is socially conditioned, as it helps to sustain or change the social status quo. Phillips et al. (2004) argue that discourse analysis is an adequate framework to understand the social production of institutionalizing and deinstitutionalizing processes. Different actors and content compete for interpretative dominance in a discourse. CDA presumes power relations between actors using "strategic ways to change the mind of others in one's own interests" (van Dijk, 1993, p. 254, emphasis in original). CDA attempts to reveal such power relations and "root out a particular kind of delusion" (Fairclough \& Wodak, 1997, p. 187) within a discourse. Therefore, both what is said and what is not said are important to understand discursive persuasion attempts.

Companies represent one strategic actor in public discourse. For the present study, it is relevant to note that corporate communication is interest-driven and thus biased towards a positive tone (Beattie, Dhanani, \& Jones, 2008; Rutherford, 2005), aims at rebuilding trust 
This is an Accepted Manuscript of an article published by Taylor \& Francis in International Journal of Strategic Communication, available online:

Lischka, J. A. (2019). Strategic Communication as Discursive Institutional Work: A Critical Discourse Analysis of Mark Zuckerberg's Legitimacy Talk at the European Parliament. International Journal of Strategic Communication. Advance online publication. https://doi.org/10.1080/1553118X.2019.1613661

after crisis (Molthagen-Schnöring, 2013), and applies impression management (Beattie et al., 2008), i.e., seeks to change the mind of others in its own interest.

This study follows an explorative analysis procedure that first outlines the structure of the communication event and the roles of the participants. Then, the topics that are addressed during the event are categorized. These steps refer to the chronological sequence of the event. Next, the rhetoric instruments are identified. After that, first, themes across the chronological topics in which the corporate actor defends the company and its conduct are classified and summarized into strategic defense narratives. Second, the discursive function of the defense narratives is identified. Therefore, van Leeuwen and Wodak's (1999) legitimacy strategies, Suchman's (1995) pragmatic, cognitive, and moral legitimacy categorization, and, against the background of the discursive work of digital platforms (Gillespie, 2010), Russell's (2017) institutional logics of Silicon Valley companies comprise the types of discursive functions. Finally, the defense narratives are compared to Lawrence and Suddaby's (2006) classification of institutional work.

\section{Material}

The analysis is based on the transcript of Mark Zuckerberg's testimony before the EU Parliament on 22 May 2018 that was video recorded and titled "European Parliament Conference of Presidents with Mark Zuckerberg - founder and CEO of Facebook." Zuckerberg's gestures can be no part of the analysis since the camera mostly frames Zuckerberg in a head and shoulder shot, showing his hands only when raised to chest level. The hearing format was unique as Zuckerberg successfully negotiated that there would be a round of questions by the representatives of the EU Parliament first, and his answers would follow the question round, instead of providing an answer after each question. This format maximizes the interviewee's freedom for structuring his answers, focusing on certain issues more than on others 
This is an Accepted Manuscript of an article published by Taylor \& Francis in International Journal of Strategic Communication, available online:

Lischka, J. A. (2019). Strategic Communication as Discursive Institutional Work: A Critical Discourse Analysis of Mark Zuckerberg's Legitimacy Talk at the European Parliament. International Journal of Strategic Communication. Advance online publication. https://doi.org/10.1080/1553118X.2019.1613661

or completely ignoring certain questions. This hearing format thus reveals which issues are aggravating for the interviewee. Also, answers may not go into detail but may remain vague, pre-defined public relations talk. Because of the greater power of the interviewee compared to a genuinely dialogic question-answer format, Zuckerberg's handling of the questions offers insights into the degree of accepting social responsibility as opposed to symbolic social responsibility and the perceived need to defend and restore Facebook's legitimacy.

\section{Context}

Political actors increasingly recognize that platforms retain their unintended power and conduct largely independently from regulation despite their negative externalities. This diagnosis discursively manifests in critical speeches, reports, and parliamentary hearings with representatives of digital platforms. During the U.S. Senate Judiciary and Commerce committee hearing regarding Facebook CEO Mark Zuckerberg on 11 April 2018, the chairmen of the Commerce Committee provided an opening statement that acknowledged Zuckerberg's entrepreneurial achievement while reminding Facebook about its responsibilities:

Mr. Zuckerberg, in many ways you and the company that you created, the story that you've created represents the American Dream. Many are incredibly inspired by what you've done. At the same time, you have an obligation, and it's up to you to ensure that that dream does not become a privacy nightmare for the scores of people who use Facebook. (Transcript courtesy of Bloomberg Government, 2018)

Digital platforms seem to show awareness of the social responsibility and regulation discourse. Acknowledging that "[ $\mathrm{t}]$ here's too much sensationalism, disinformation and polarization in the world today. Social media enables people to spread information faster than ever before, and if we don't specifically tackle these problems, then we end up amplifying 
This is an Accepted Manuscript of an article published by Taylor \& Francis in International Journal of Strategic Communication, available online:

Lischka, J. A. (2019). Strategic Communication as Discursive Institutional Work: A Critical Discourse Analysis of Mark Zuckerberg's Legitimacy Talk at the European Parliament. International Journal of Strategic Communication. Advance online publication. https://doi.org/10.1080/1553118X.2019.1613661

them" (Zuckerberg, 2018), Zuckerberg recognizes Facebook's social responsibility in the public sphere. After the Cambridge Analytica scandal, such symbolic communication became insufficient, and representatives of digital platforms were forced into a justification dialogue with political actors. Zuckerberg's public hearings before the U.S. Senate and the EU Parliament were also called an "apology tour" by the press (Frenkel, 2018, para 1). The hearings can be regarded as roundtables between digital platforms and their regulatory stakeholders, which represents a deliberative type of CSR communication according to Seele and Lock (2015).

In his testimony before the U.S. Senate, Zuckerberg stated in his introductory comments that "Facebook is an idealistic and optimistic company for most of our existence," describing examples of positive externalities of Facebook in communications, businesses, and the economy, and apologized for not taking "a broad enough view of our responsibilities" (Transcript courtesy of Bloomberg Government, 2018). He uses almost the same wording to apologize to the EU Parliament about six weeks later, on 22 May.

\section{Findings}

\section{The Structure of Mark Zuckerberg's EU Hearing}

The hearing lasted 1 hour and 28 minutes and had six phases (summarized in Table 2). First, in a short speech the President of the European Parliament introduced Zuckerberg to the meeting and addressed Facebook's negative externalities for users and their communication in democratic societies. Next, Zuckerberg read an opening statement from a manuscript in which he emphasized common values between Facebook and Europe, including "importance of human rights, and the need for community, to the love of technology and all the potential it can bring," focused on the positive externalities of Facebook, apologized by stating, "We didn't take a broad enough view of our responsibility. And that was a mistake, 
This is an Accepted Manuscript of an article published by Taylor \& Francis in International Journal of Strategic Communication, available online:

Lischka, J. A. (2019). Strategic Communication as Discursive Institutional Work: A Critical Discourse Analysis of Mark Zuckerberg's Legitimacy Talk at the European Parliament. International Journal of Strategic Communication. Advance online publication. https://doi.org/10.1080/1553118X.2019.1613661

and I'm sorry for it," and concluded with an explanation of extensive substantive action that Facebook takes "to keep people safe." The opening statement was followed by a collection of questions from the present Members of Parliament.

After the questions, Zuckerberg replied collectively in a monologue during which he identified and divided the questions into nine topics. Thereby, he takes up issues and expressions from his opening statement and explains those in greater detail. Zuckerberg selects the topics he addresses based on the frequency of questions and on whether the question provides an opportunity to convey legitimacy narratives. After addressing several topics, Zuckerberg asks the rhetorical question "what else" while looking into his notes, and Members of Parliament attempt to take guidance by reminding him of a topic he did not address ("shadow profiles"), which is however ignored by Zuckerberg. Towards the end of his testimony, Zuckerberg says, "I want to be sensitive to time because we are 15 minutes over the scheduled meeting," while acknowledging that there "were a lot of specific questions that I didn't get to specifically answer," after which two participants spontaneously follow up on questions that were not addressed. Mark Zuckerberg replies, "I'll make sure we'll follow up and get you answers to those," rapidly putting his palms on the table and slightly rolling back in his chair. This gesture underlines his decision to end the meeting and suggests eagerness to leave. After Zuckerberg's agreement to provide written answers to the remaining questions, the President closes the hearing.

[Table 2 about here]

\section{The Defense Narratives of Mark Zuckerberg's EU Testimony}

Pragmatic legitimacy. The major narratives of Zuckerberg's testimony aim at signaling pragmatic legitimacy through three closely related corporate ability narratives. The first focuses on the utility of Facebook for private and corporate users, which is expressed using 
This is an Accepted Manuscript of an article published by Taylor \& Francis in International Journal of Strategic Communication, available online:

Lischka, J. A. (2019). Strategic Communication as Discursive Institutional Work: A Critical Discourse Analysis of Mark Zuckerberg's Legitimacy Talk at the European Parliament. International Journal of Strategic Communication. Advance online publication. https://doi.org/10.1080/1553118X.2019.1613661

instrumental rationalization. Zuckerberg highlights positive externalities of Facebook's products and services in his introduction just before his apology as well as throughout his answer monologue (strategic defense narrative A in Figure 2). Therefore, he lists examples of positive effects of Facebook communication for users and stresses positive effects for businesses and the economy, which is "all the good that technology and connecting people can bring." He refers to Facebook's safety check tool that "tens of thousands of people" use to communicate that they are safe after terrorist attacks. Further, Facebook contributes to refugee integration since refugees can "stay in touch with their loved ones back home and find new communities here" using Facebook. During his testimony, Zuckerberg refers to Facebook's well-being research, although the topic was not brought up in the questions, which reveals that using Facebook for staying in touch with "loved ones" instead of using Facebook for news consumption is very positive for users' well-being. Using the authorization strategy through references to research underlines Facebook's utility for users. Besides these positive effects for society, the economy is indirectly positively affected since businesses using Facebook create new jobs: "There are 18 million small businesses here in Europe" of which "almost half" hired more people "as a result of the use of our tools." He describes in a vow-like tone that Facebook has a

pro-competitive effect of enabling all these small businesses to now have access to the same kinds of marketing and advertising tools and be able to reach customers in sophisticated technological ways that previously only large business had the means to do. And that's something that we're very proud of.

This elaborate talk portrays Facebook's products and services as socially and economically valuable for many private and business users. 
This is an Accepted Manuscript of an article published by Taylor \& Francis in International Journal of Strategic Communication, available online:

Lischka, J. A. (2019). Strategic Communication as Discursive Institutional Work: A Critical Discourse Analysis of Mark Zuckerberg's Legitimacy Talk at the European Parliament. International Journal of Strategic Communication. Advance online publication. https://doi.org/10.1080/1553118X.2019.1613661

The second emphasis for signaling pragmatic legitimacy lies in mythopoesis. Zuckerberg uses Facebook's dorm room founding myth to remind people about the fast development of the company from a small start-up due to its utility for users and the fact that the company always had the best intentions and acted in the interest of its users (narrative B in Figure 2). Zuckerberg states,

So, if you look back on the history of how we've operated. I don't want to get started in my dorm room in college because it was just me and because we didn't have the AI [artificial intelligence] tools at the time to be able to look through a lot of the content to understand what was a violation of our community standards and what wasn't. Our policy for most of the history of the company has been to have our community flag things for us and then us to look at them reactively.

This mythologizing of Facebook through telling stories about its past also aims at maintaining Facebook as a corporate institution according to Lawrence and Suddaby (2006) and therefore strives to advocate cognitive beyond pragmatic legitimacy.

However, third, immoral users and developers misused Facebook's products and services for their own interests (narrative C). Facebook's fault lies not in having developed flawed products and services but in not recognizing misuses quickly enough: "In 2016, we were too slow to identify Russian interference in the U.S. presidential election." Now, Facebook strives at "making sure that we can do a better job of governing the system, keeping bad content out. In the ways that we do that is by understanding how people are using the system." This argument tries to reframe the product-harm crisis into a supplier crisis (Jong \& van der Meer, 2017). Thus, mythopoesis is used as an explanation that functions as an 
This is an Accepted Manuscript of an article published by Taylor \& Francis in International Journal of Strategic Communication, available online:

Lischka, J. A. (2019). Strategic Communication as Discursive Institutional Work: A Critical Discourse Analysis of Mark Zuckerberg's Legitimacy Talk at the European Parliament. International Journal of Strategic Communication. Advance online publication. https://doi.org/10.1080/1553118X.2019.1613661

instrumental rationalization strategy for reducing blame ascriptions to Facebook. This issue is related to solution-oriented and substantive action arguments described in the next section.

Moral legitimacy. Wherever possible, Zuckerberg addresses ethical responsibilities to signal moral legitimacy. His responsibility narrative indicates that evaluating Facebook's products and services against the background of ethical responsibility has been a learning process. After apologizing for not taking "a broad enough view," Zuckerberg recognizes that, "Now, we think our responsibility is greater." The numerous substantive undertakings to curtail negative externalities (narrative D) are embedded in a talk of acknowledging ethical responsibility (narrative E). Zuckerberg states, "Keeping people safe will always be more important than maximizing our profits" and suggests that ethical responsibilities are more important than business responsibilities, which is in contrast to Carroll's (1991) CSR hierarchy. Yet, this depiction may be rational in the context of the hearing, indicating that Facebook strives to be a good corporate citizen.

Zuckerberg accentuates the company's diligence as well as efficiency regarding substantive action on the one hand (narrative D). Speaking of diligence, he states that Facebook "realized that we need to do a much better job of addressing that [misuse] quickly." Further, Facebook makes the "necessary investments" to go through "the areas that are the most sensitive and have the highest risk of harm: terror, bullying, self-harm, election integrity." This includes Facebook's ability as a "big company" "to start developing more AI tools" and "to employ tens of thousands of people" who will review potentially problematic content. Besides investments, Facebook understood the motivation behind fake news distributors, which are purely economically driven, similar to spammers, and thus Facebook took action to reduce their advertising revenue, which will solve the problem of fake news sites. Zuckerberg uses numbers to prove the efficiency of their substantive actions. For instance, Facebook 
This is an Accepted Manuscript of an article published by Taylor \& Francis in International Journal of Strategic Communication, available online:

Lischka, J. A. (2019). Strategic Communication as Discursive Institutional Work: A Critical Discourse Analysis of Mark Zuckerberg's Legitimacy Talk at the European Parliament. International Journal of Strategic Communication. Advance online publication. https://doi.org/10.1080/1553118X.2019.1613661

"took down more than 30,000 [fake] accounts" in the French presidential election and has "already investigated thousands of apps and [...] taken down more than 200" after the Cambridge Analytical scandal. Facebook’s “AI systems now can flag 99 percent of the ISIS and Al Qaeda related content that we end up taking down," and the response time to harm or suicide videos on Facebook Live "is now less than ten minutes." In conclusive sentences, Zuckerberg summarizes Facebook's efficiency ability stating that "we have been able to significantly improve" and "we are already making significant progress in doing that." Moreover, Facebook considers regulation for reducing negative externalities as reasonable, acknowledging that "the Internet is becoming increasingly important in people's lives. Some sort of regulation is important and inevitable." This also suggest Facebook's willingness to adapt to new regulation.

On the other hand, a third theme within the substantive action narrative is related to modesty and imperfection, which limit efficiency ability. Zuckerberg states "we'll never be perfect on this [prohibit the distribution of 'bad content']" because of the misusing users or developers who make it "an arms race" regarding AI technology in which Facebook nevertheless "will constantly be working to stay ahead." Further, Zuckerberg notes that "many months" are needed to sufficiently react to the problems related to negative externalities of Facebook. Regarding fake news identification through third-party fact checkers, Facebook is "trying to roll that out around the world," which, however, "requires having specific fact checking partners in every country and in every language. [...] We know that there is a lot more to do there." Therefore, corporate audiences can expect the correction of defects to be a long-term, ongoing process.

Thus, Zuckerberg signals that Facebook has been learning how to react to negative externalities. In Facebook's understanding, negative externalities are caused by misuse and 
This is an Accepted Manuscript of an article published by Taylor \& Francis in International Journal of Strategic Communication, available online:

Lischka, J. A. (2019). Strategic Communication as Discursive Institutional Work: A Critical Discourse Analysis of Mark Zuckerberg's Legitimacy Talk at the European Parliament. International Journal of Strategic Communication. Advance online publication. https://doi.org/10.1080/1553118X.2019.1613661

not by their products or services. This suggests that Facebook will continue to learn how to handle negative externalities since future misuse is not yet known, and they will not be able to prevent negative externalities before they occur. Although Zuckerberg portrays Facebook's approach to identifying problematic content as actively correcting compared to their original approach of letting users flag "bad content," the new approach retains a reactive component as there are no references to anticipating future negative externalities. Hence, there are limits to Facebook's adaptation ability, although their willingness to conform is high.

Besides general symbolic responsibility statements, the application of social responsibility is revealed in two value-laden examples. First, Zuckerberg declares that Facebook refrains from evaluating political stances. He affirms that Facebook is a "platform for all ideas," taking up aspects of Habermas' ideal of a public sphere:

It's very important to me that we are a service that allows for a wide variety of political discourse. We regard this as a big part of our responsibility. And I can commit to you here today that we have never and will not make decisions about what content is allowed or how we do ranking on the basis of a political orientation. That's an important philosophical point for me that I'm proud to be able to commit to.

This vow-like statement can be considered a pragmatic speech act of an unalterable value declaration.

Second, regarding fake news, Zuckerberg states, "We don't want to be in a position as Facebook is saying what is true or false. We think that's not the right position for us to be in." Consequently, Facebook defers to the findings of fact checkers who assign responsibility to external parties. In case of fake news, Facebook marks it and surrounds it with more content from other angles "so people can have a more rounded view." 
This is an Accepted Manuscript of an article published by Taylor \& Francis in International Journal of Strategic Communication, available online:

Lischka, J. A. (2019). Strategic Communication as Discursive Institutional Work: A Critical Discourse Analysis of Mark Zuckerberg's Legitimacy Talk at the European Parliament. International Journal of Strategic Communication. Advance online publication. https://doi.org/10.1080/1553118X.2019.1613661

Both examples reveal that Facebook wishes to be a neutral platform fulfilling the criteria of the constructionist public sphere that focuses on including the periphery and oppressed (Ferree, Gamson, Gerhards, \& Rucht, 2002). Being a "platform for all ideas" also refers to the Silicon Valley mantra that information is free and should be accessible for everyone (Healey \& Woods, 2017). Thus, ethical responsibilities are recognized but interpreted from a techno-utilitarian view.

These moral narratives explain how Facebook adapts to external expectations, indicating Facebook's conformity with external expectations. According to Scherer et al. (2013), conformity narratives signal cognitive legitimacy. Thus, Zuckerberg's moral conformity narratives may also play into Facebook's cognitive legitimacy.

Cognitive legitimacy. Mark Zuckerberg conveys Silicon Valley logics of technology superiority throughout the hearing and systemizes Facebook's technology (narrative F).

In his introductory statement, Zuckerberg refers to a democratic value and a social media characteristic, stating that Europe and Facebook share the same values of "human rights, and the need for community," climaxing with the tech-utopian view "the love of technology and all the potential it can bring." He also describes Facebook's ideology with the focus on "all the good that technology $[\ldots]$ can bring." More specifically, one technology is highlighted as having the most potential. Throughout his testimony, Zuckerberg frequently portrays AI as being able to solve every problem: "One of the things I'm proud of is that our AI systems now can flag a 99 percent" of terror content, "the game plan is [...] building more AI tools" for identifying fake accounts, "we have the possibility to start developing more AI tools" for fake news detection, and "so we built AI tools" for detecting harm or suicide videos on Facebook Live. This indicates that digital technology, more specifically AI, is capable of solving every problem on Facebook. Facebook's application of AI also 
This is an Accepted Manuscript of an article published by Taylor \& Francis in International Journal of Strategic Communication, available online:

Lischka, J. A. (2019). Strategic Communication as Discursive Institutional Work: A Critical Discourse Analysis of Mark Zuckerberg's Legitimacy Talk at the European Parliament. International Journal of Strategic Communication. Advance online publication. https://doi.org/10.1080/1553118X.2019.1613661

suggests an increase in Facebook's utility, which signals corporate ability and thus pragmatic legitimacy.

This tech-utilitarian logic is specifically relevant in his speech about regulation requirements, which include "that they [regulatory frameworks] allow for innovation, that don't inadvertently prevent new technologies like AI from being developed." The tech-utopian ideology appears to be more important than potential competition as Zuckerberg demands that regulation should not lay an "undue burden" on "the next student sitting in a college dorm room like I was 14 years ago [...] on being able to build the next great products." Zuckerberg recognizes that the regulation discourse is "an ongoing conversation that we look forward to participating in," as conveying tech-utopian views to the regulation body is strategically important. Thus, technological innovation is represented as a necessary path for society, and therefore freedom of technological innovation deserves a maximum of protection. This combination of techno-utopian ideology and striving for minimum regulation puts Zuckerberg's speech in a techno-libertarian perspective. In Lawrence and Suddaby's (2006) sense of advocacy, Zuckerberg strives to mobilize political and regulatory support for the lowest possible regulation of AI.

Besides outlining the superior capability of technology, Zuckerberg subjectifies Facebook's technology. He refers to Facebook technology behind its products and services as "the system." For instance, "there were a lot of different apps that were using the system," "we can do a better job of governing the system" by "understanding how people are using the system," and "manage the system." This suggests that Facebook's technology is complex and inscrutable, and thus Zuckerberg must send "someone to do a full hearing soon to answer more of the technical questions as well," as he suggests towards the end of his statement. It also implies that how "the system" works not only depends on Facebook but on other users 
This is an Accepted Manuscript of an article published by Taylor \& Francis in International Journal of Strategic Communication, available online:

Lischka, J. A. (2019). Strategic Communication as Discursive Institutional Work: A Critical Discourse Analysis of Mark Zuckerberg's Legitimacy Talk at the European Parliament. International Journal of Strategic Communication. Advance online publication. https://doi.org/10.1080/1553118X.2019.1613661

or developers that might be able to exploit it for their interests, which is an attempt to limit Facebook's liability. Also, the systemization suggests corporate ability and may play into Facebook's pragmatic legitimacy.

Unanswered questions. Zuckerberg remains silent to the "specific" and "more technical" questions. Although asked through interjection or further inquiry after Zuckerberg finished his answer monologue, questions about shadow profiles, cross-platform data use, and targeting of political advertising remained unanswered. These topics address the commodification of users and user data, which is at the heart of Facebook's business model and suggest that Facebook performs surveillance capitalism. Answers to these questions could be framed in pragmatic legitimacy talk indicating that users benefit from analyzing their user data by receiving suggestions that meet their interests. At the same time, Facebook's commodification of user data would become a focus, which Zuckerberg avoids throughout his talk. The commodification would counterbalance and risk disparaging Facebook's thoroughly illustrated pragmatic, moral, and cognitive legitimacy. Because certain questions are unanswered, the audience is unable to conclusively evaluate Facebook's conduct against the background of social responsibility. Zuckerberg's strict avoidance therefore adds an aftertaste of whitewashing to the talk, which compromises the credibility of his talk and thus Facebook's moral legitimacy (Seele \& Lock, 2015).

Synopsis. Zuckerberg's talk at the EU Parliament signals all three corporate legitimacy dimensions (Figure 2) and is designed to counterbalance the negative externalities addressed by politicians with positive externalities and utility of Facebook's products and services. Thereby, Zuckerberg uses a wide range of discursive strategies. All addressed topics are related to pragmatic legitimacy narratives. The narratives around topics that suggest negative externalities are additionally linked to moral legitimacy. Zuckerberg extensively emphasizes 
This is an Accepted Manuscript of an article published by Taylor \& Francis in International Journal of Strategic Communication, available online:

Lischka, J. A. (2019). Strategic Communication as Discursive Institutional Work: A Critical Discourse Analysis of Mark Zuckerberg's Legitimacy Talk at the European Parliament. International Journal of Strategic Communication. Advance online publication. https://doi.org/10.1080/1553118X.2019.1613661

corporate ability and Facebook's internal revision of practices. When it comes to cognitive legitimacy, Zuckerberg indicates that AI will be used to formalize Facebook's operations and advocates Silicon Valley tech logics. Finally, he popularizes new models when suggesting minimum regulation for AI. According to Suchman's (1995) legitimation strategies, the speech seeks to gain pragmatic and cognitive legitimacy and to repair Facebook's moral legitimacy. Zuckerberg advocates techno-libertarian values and thus conducts institutional work in Lawrence and Suddaby's (2006) sense. Thus, Zuckerberg employs an almost complete and perfectly arranged variation of discursive legitimacy strategies, using the hearing as a deliberative CSR roundtable.

[Figure 2 about here]

\section{Conclusion}

Neo-institutional theory suggests that external legitimacy expectations function as conformity constraints for company behavior. The wide conformation of companies to CSR expectations confirms this view. Yet, discursive institutionalism argues that external expectations are socially constructed, which also includes the discursive manipulation of corporate actors. That is, corporate actors not only passively adapt to but can actively shape external expectations. Conformation and manipulation strategies for gaining corporate legitimacy are identified in Suchman (1995) and central in Scherer et al.'s (2013) legitimacy management strategies. Since legitimacy is vital for the sustained success of a company, corporate legitimacy communication, including CSR communication, is an important issue of strategic communication. Integrating conformity and manipulation, this study conceptualizes strategic communication as a means for discursively signaling conformity as well as discursively manipulating external legitimacy expectations and judgments, emphasizing the capacity of strategic communication to discursively construct institutions. 
This is an Accepted Manuscript of an article published by Taylor \& Francis in International Journal of Strategic Communication, available online:

Lischka, J. A. (2019). Strategic Communication as Discursive Institutional Work: A Critical Discourse Analysis of Mark Zuckerberg's Legitimacy Talk at the European Parliament. International Journal of Strategic Communication. Advance online publication. https://doi.org/10.1080/1553118X.2019.1613661

This study demonstrates how companies can simultaneously discursively adapt to and manipulate external legitimacy expectations using strategic communication. Against the background of the legitimacy negotiation of digital platforms that is caused by a productharm crisis in which corporate audiences address yet unmet social responsibility expectations, this study critically analyzes the testimony of Facebook's founder and CEO Mark Zuckerberg concerning discursive legitimacy defense at the European Parliament in May 2018. Zuckerberg's testimony strives to manipulate the legitimacy perception of external audiences as well as attempts to alter the institutional views under which Facebook's legitimacy is judged. According to Lawrence and Suddaby (2006), Zuckerberg can be conceptualized as an institutional entrepreneur who conducts institutional work through reconfiguring institutions while highlighting the importance of technology for solving social problems: While striving to repair Facebook's legitimacy, Zuckerberg's talk also aims at mobilizing political and regulatory support for minimum regulation of AI.

The study therefore also contributes to an understanding of the role digital platforms seek to play in society. Zuckerberg's techno-libertarian argumentation suggests that without being allowed to experiment with innovative technology, solutions to social problems will not be found. Thereby, Zuckerberg prepares the path for an AI-technologized future at Facebook and beyond. This technological superiority mantra comprises a central logic of Silicon Valley companies (Healey \& Woods, 2017; Russell, 2017). Once institutionalized more broadly, advocating AI may lead to overlooking other possible methods of solving the negative externalities of digital platforms for society. Therefore, future research should critically analyze the power relations and institutional work regarding creating new institutions and disrupting existing institutions in the unfolding discourse about the regulation of digital platforms, in which Zuckerberg announced his company's participation. 
This is an Accepted Manuscript of an article published by Taylor \& Francis in International Journal of Strategic Communication, available online:

Lischka, J. A. (2019). Strategic Communication as Discursive Institutional Work: A Critical Discourse Analysis of Mark Zuckerberg's Legitimacy Talk at the European Parliament. International Journal of Strategic Communication. Advance online publication. https://doi.org/10.1080/1553118X.2019.1613661

The present study is limited by its focus on one specific communication event between Facebook's CEO and European politicians that does not represent Facebook's corporate communication in general. However, this deliberative stakeholder roundtable provides insight into an international digital platform's legitimacy defense facing the expectations of politicians who wish to regulate digital platforms and hold them accountable for negative externalities. Future research may find an analysis over time an insightful approach comparing the social responsibility talk of representatives of digital platforms between the U.S. and other countries. As Suchman (1995, p. 592) argues, an orchestrated communication by a group of companies becomes a powerful "collective evangelism" occupying an issue. That is, it is relevant to analyze how various digital platforms frame the roles and responsibilities of themselves and new technology in society. Further, this study cannot give evidence regarding the legitimacy perception of Zuckerberg's talk on the judgement level or the micro level of users (Bitektine \& Haack, 2015). It would, however, be informative to analyze in what way Zuckerberg's legitimacy signals are perceived and whether they contribute to legitimacy judgments of external audiences.

Future research should also investigate to what extend social expectations influence CSR decisions of digital platforms and how digital platforms respond to social expectations. This study suggests that digital platforms rather employ a manipulation instead of confirmation strategy, which is the preferred mode when costs of organizational change are high (Scherer et al., 2013) and new models ought to be promoted (Suchman, 1995). Digital platforms will remain relevant for communication and democracy in digital societies. Their importance calls for holding digital platforms accountable concerning negative externalities for individual users and the public. Thus, analyzing the discursive signals within the strategic 
This is an Accepted Manuscript of an article published by Taylor \& Francis in International Journal of Strategic Communication, available online:

Lischka, J. A. (2019). Strategic Communication as Discursive Institutional Work: A Critical Discourse Analysis of Mark Zuckerberg's Legitimacy Talk at the European Parliament. International Journal of Strategic Communication. Advance online publication. https://doi.org/10.1080/1553118X.2019.1613661

communication of digital platforms will remain crucial to further "examine the roles they aim to play, and the terms by which they hope to be judged" (Gillespie, 2010, p. 347).

\section{References}

Alvesson, M., Hallett, T., \& Spicer, A. (2019). Uninhibited Institutionalisms. Journal of Management Inquiry, 51, 105649261882277.

https://doi.org/10.1177/1056492618822777

Ashforth, B. E., \& Gibbs, B. W. (1990). The double-edge of organizational legitimation. Organization Science, 1(2), 177-194. https://doi.org/10.1287/orsc.1.2.177

Bannister, F., \& Connolly, R. (2018). The fourth power: ICT and the role of the administrative state in protecting democracy. Information Polity, 23(3), 307-323. https://doi.org/10.3233/IP-180072

Beattie, V., Dhanani, A., \& Jones, M. J. (2008). Investigating presentational change in U.K. annual reports: A longitudinal perspective. Journal of Business Communication, 45(2), 181-222. https://doi.org/10.1177/0021943607313993

Bitektine, A., \& Haack, P. (2015). The "Macro" and the "Micro" of Legitimacy: Toward a Multilevel Theory of the Legitimacy Process. Academy of Management Review, 40(1), 49-75. https://doi.org/10.5465/amr.2013.0318

Campbell, J. L. (2007). Why would corporations behave in socially responsible ways? An institutional theory of corporate social responsibility. Academy of Management Review, 32(3), 946-967. https://doi.org/10.5465/AMR.2007.25275684

Carroll, A. B. (1991). The pyramid of corporate social responsibility: Toward the moral management of organizational stakeholders. Business Horizons, 34(4), 39-48. https://doi.org/10.1016/0007-6813(91)90005-G 
This is an Accepted Manuscript of an article published by Taylor \& Francis in International Journal of Strategic Communication, available online:

Lischka, J. A. (2019). Strategic Communication as Discursive Institutional Work: A Critical Discourse Analysis of Mark Zuckerberg's Legitimacy Talk at the European Parliament. International Journal of Strategic Communication. Advance online publication. https://doi.org/10.1080/1553118X.2019.1613661

Castelló, I., \& Lozano, J. M. (2011). Searching for New Forms of Legitimacy Through

Corporate Responsibility Rhetoric. Journal of Business Ethics, 100(1), 11-29.

https://doi.org/10.1007/s10551-011-0770-8

Clemente, M., \& Roulet, T. J. (2015). Public opinion as a source of deinstitutionalization:

A "Spiral of Silence" approach. Academy of Management Review, 40(1), 96-114.

https://doi.org/10.5465/amr.2013.0279

Coyle, D. (2018). Platform dominance: The shortcomings of antitrust policy. In M. Moore \& D. Tambini (Eds.), Digital Dominance: The Power of Google, Amazon, Facebook, and Apple (pp. 50-70). Oxford: Oxford University Press, Incorporated.

Dawar, N., \& Pillutla, M. M. (2010). Impact of Product-Harm Crises on Brand Equity: The Moderating Role of Consumer Expectations. Journal of Marketing Research, 37(2), 215-226. https://doi.org/10.1509/jmkr.37.2.215.18729

DiMaggio, P. J. (1988). Interest and agency in institutional theory. In L. G. Zucker (Ed.), Institutional patterns and organizations: Culture and environment (pp. 3-21). Cambridge, MA: Ballinger.

DiMaggio, P. J., \& Powell, W. W. (1983). The iron cage revisited: Institutional isomorphism and collective rationality in organizational fields. American Sociological Review, $48(2), 147-160$.

Fairclough, N. (1995). Media discourse. London, New York: E. Arnold.

Fairclough, N., \& Wodak, R. (1997). Critical discourse analysis. In T. A. van Dijk (Ed.), Discourse as social interaction (pp. 258-284). London: Sage.

Ferree, M. M., Gamson, W. A., Gerhards, J., \& Rucht, D. (2002). Four Models of the Public Sphere in Modern Democracies. Theory and Society, 31(3), 289-324. 
This is an Accepted Manuscript of an article published by Taylor \& Francis in International Journal of Strategic Communication, available online:

Lischka, J. A. (2019). Strategic Communication as Discursive Institutional Work: A Critical Discourse Analysis of Mark Zuckerberg's Legitimacy Talk at the European Parliament. International Journal of Strategic Communication. Advance online publication. https://doi.org/10.1080/1553118X.2019.1613661

Frenkel, S. (2018, May 22). Mark Zuckerberg to Apologize Again, This Time to European

Parliament. The New York Times. Retrieved from https://www.ny-

times.com/2018/05/22/technology/mark-zuckerberg-apologize-european-parliament.html

Gillespie, T. (2010). The politics of 'platforms'. New Media \& Society, 12(3), 347-364. https://doi.org/10.1177/1461444809342738

Healey, K., \& Woods, R. H. (2017). Processing Is Not Judgment, Storage Is Not Memory: A Critique of Silicon Valley's Moral Catechism. Journal of Media Ethics, 32(1), 2-15. https://doi.org/10.1080/23736992.2016.1258990

Johansen, T. S., \& Ellerup Nielsen, A. (2011). Strategic stakeholder dialogues: a discursive perspective on relationship building. Corporate Communications: an International Journal, 16(3), 204-217. https://doi.org/10.1108/13563281111156871

Jong, M. D. T. de, \& van der Meer, M. (2017). How Does It Fit? Exploring the Congruence Between Organizations and Their Corporate Social Responsibility (CSR) Activities. Journal of Business Ethics, 143(1), 71-83. https://doi.org/10.1007/s10551-015$2782-2$

Kim, S. (2014). What's Worse in Times of Product-Harm Crisis? Negative Corporate Ability or Negative CSR Reputation? Journal of Business Ethics, 123(1), 157-170. https://doi.org/10.1007/s10551-013-1808-x

Kim, S., \& Rader, S. (2010). What they can do versus how much they care. Journal of Communication Management, 14(1), 59-80. https://doi.org/10.1108/13632541011017816 
This is an Accepted Manuscript of an article published by Taylor \& Francis in International Journal of Strategic Communication, available online:

Lischka, J. A. (2019). Strategic Communication as Discursive Institutional Work: A Critical Discourse Analysis of Mark Zuckerberg's Legitimacy Talk at the European Parliament. International Journal of Strategic Communication. Advance online publication. https://doi.org/10.1080/1553118X.2019.1613661

Kostova, T., Roth, K., \& Dacin, M. T. (2008). Institutional Theory in the Study of Multinational Corporations: A Critique and New Directions. Academy of Management Review, 33(4), 994-1006. https://doi.org/10.5465/amr.2008.34422026

Lawrence, T. B., \& Suddaby, R. (2006). Institutions and Institutional Work. In The SAGE Handbook of Organization Studies (pp. 215-254). 1 Oliver's Yard, 55 City Road, London EC1Y 1SP United Kingdom: SAGE Publications Ltd. https://doi.org/10.4135/9781848608030.n7

Lock, I., \& Schulz-Kappe, C. (2019). Credible corporate social responsibility (CSR) communication predicts legitimacy. Corporate Communications: an International Journal, 24(1), 2-20. https://doi.org/10.1108/CCIJ-07-2018-0071

Maguire, S., Hardy, C., \& Lawrence, T. B. (2004). Institutional entrepreneurship in emerging fields: HIV/AIDS treatment advocacy in Canada. Academy of Management Journal, 47(5), 657-679. https://doi.org/10.2307/20159610

Maguire, S., \& Hardy, C. (2016). The Emergence of New Global Institutions: A Discursive Perspective. Organization Studies, 27(1), 7-29.

https://doi.org/10.1177/0170840606061807

Meyer, J. W., \& Rowan, B. (1977). Institutionalized organizations: Formal structure as myth and ceremony. The American Journal of Sociology, 83(2), 340-363.

Molthagen-Schnöring, S. (2013). Rhetoric in times of crises: How financial institutions try to restore confidence. Language and Dialogue, 3(3), 371-387. https://doi.org/10.1075/ld.3.3.02mol

Napoli, P. M., \& Caplan, R. (2017). Why Media Companies Insist They’re Not Media Companies, Why They're Wrong, and Why It Matters. First Monday, 22(5). Retrieved from http://firstmonday.org/ojs/index.php/fm/article/view/7051/6124 
This is an Accepted Manuscript of an article published by Taylor \& Francis in International Journal of Strategic Communication, available online:

Lischka, J. A. (2019). Strategic Communication as Discursive Institutional Work: A Critical Discourse Analysis of Mark Zuckerberg's Legitimacy Talk at the European Parliament. International Journal of Strategic Communication. Advance online publication. https://doi.org/10.1080/1553118X.2019.1613661

Naughton, J. (2018). Platform Power and Responsibility in the Attention Economy. In M.

Moore \& D. Tambini (Eds.), Digital Dominance: The Power of Google, Amazon, Facebook, and Apple (pp. 371-395). Oxford: Oxford University Press, Incorporated.

Palazzo, G., \& Scherer, A. G. (2006). Corporate Legitimacy as Deliberation: A Communicative Framework. Journal of Business Ethics, 66(1), 71-88.

https://doi.org/10.1007/s10551-006-9044-2

Phillips, N., Lawrence, T. B., \& Hardy, C. (2004). Discourse and institutions. Academy of Management Review, 29(4), 635-652.

Pickard, V. (2017). The big picture: Misinformation society. Retrieved from http://www.publicbooks.org/the-big-picture-misinformation-society/

Russell, F. M. (2017). The New Gatekeepers: An Institutional-level View of Silicon Valley and the Disruption of Journalism. Journalism Studies, 7(2), 1-18. https://doi.org/10.1080/1461670X.2017.1412806

Rutherford, B. A. (2005). Genre analysis of corporate annual report narratives: A corpus linguistics-based approach. Journal of Business Communication, 42(4), 349-378. https://doi.org/10.1177/0021943605279244

Scherer, A. G., \& Palazzo, G. (2011). The New Political Role of Business in a Globalized World: A Review of a New Perspective on CSR and its Implications for the Firm, Governance, and Democracy. Journal of Management Studies, 48(4), 899-931. https://doi.org/10.1111/j.1467-6486.2010.00950.x

Scherer, A. G., Palazzo, G., \& Seidl, D. (2013). Managing Legitimacy in Complex and Heterogeneous Environments: Sustainable Development in a Globalized World. Journal of Management Studies, 50(2), 259-284. https://doi.org/10.1111/joms.12014 
This is an Accepted Manuscript of an article published by Taylor \& Francis in International Journal of Strategic Communication, available online:

Lischka, J. A. (2019). Strategic Communication as Discursive Institutional Work: A Critical Discourse Analysis of Mark Zuckerberg's Legitimacy Talk at the European Parliament. International Journal of Strategic Communication. Advance online publication. https://doi.org/10.1080/1553118X.2019.1613661

Schmidt, V. A. (2008). Discursive Institutionalism: The Explanatory Power of Ideas and

Discourse. Annual Review of Political Science, 11(1), 303-326.

https://doi.org/10.1146/annurev.polisci.11.060606.135342

Schultze, Q. J. (2004). Habits of the high-tech heart: Living virtuously in the information age. Grand Rapids, Mich.: Baker Books.

Seele, P., \& Lock, I. (2015). Instrumental and/or Deliberative? A Typology of CSR Communication Tools. Journal of Business Ethics, 131(2), 401-414.

https://doi.org/10.1007/s10551-014-2282-9

Suchman, M. C. (1995). Managing legitimacy: Strategic and institutional approaches. Academy of Management Review, 20(3), 571-610.

https://doi.org/10.5465/AMR.1995.9508080331

Taddeo, M., \& Floridi, L. (2016). The Debate on the Moral Responsibilities of Online Service Providers. Science and Engineering Ethics, 22(6), 1575-1603.

https://doi.org/10.1007/s11948-015-9734-1

Tan, J., \& Tan, A. E. (2012). Business Under Threat, Technology Under Attack, Ethics Under Fire: The Experience of Google in China. Journal of Business Ethics, 110(4), 469-479. https://doi.org/10.1007/s10551-012-1494-0

Tao, W. (2016). How Consumers' Pre-Crisis Associations and Attitude Certainty Impact Their Responses to Different Crises. Communication Research, 45(6), 815-839. https://doi.org/10.1177/0093650217733361

Tost, L. P. (2011). An integrative model of legitimacy judgments. Academy of Management Review, 36(4), 686-710. https://doi.org/10.5465/amr.2010.0227 
This is an Accepted Manuscript of an article published by Taylor \& Francis in International Journal of Strategic Communication, available online:

Lischka, J. A. (2019). Strategic Communication as Discursive Institutional Work: A Critical Discourse Analysis of Mark Zuckerberg's Legitimacy Talk at the European Parliament. International Journal of Strategic Communication. Advance online publication. https://doi.org/10.1080/1553118X.2019.1613661

Transcript courtesy of Bloomberg Government (2018, April 10). Transcript of Mark Zuckerberg's Senate hearing. The Washington Post. Retrieved from https://www.washingtonpost.com/news/the-switch/wp/2018/04/10/transcript-of-mark-zuckerbergs-senatehearing/?noredirect=on\&utm_term=.c9ae77252e9f

Vallentin, S. (2007). Private Management and Public Opinion. Business \& Society, 48(1), 60-87. https://doi.org/10.1177/0007650307300443

Van Dijk, T. A. (1993). Principles of Critical Discourse Analysis. Discourse \& Society, 4(2), 249-283. https://doi.org/10.1177/0957926593004002006

Van Leeuwen, T., \& Wodak, R. (1999). Legitimizing immigration control: A discoursehistorical analysis. Discourse Studies, 1(1), 83-118. https://doi.org/10.1177/1461445699001001005

Van Riel, C. B.M., \& Fombrun, C. J. (2007). Essentials of corporate communication: Implementing practices for effective reputation management. Abingdon: Routledge.

Waddock, S. (2008). Building a New Institutional Infrastructure for Corporate Responsibility. Academy of Management Perspectives, 22(3), 87-108. https://doi.org/10.5465/AMP.2008.34587997

$\mathrm{Wu}, \mathrm{T}$. (2016). The attention merchants: The epic scramble to get inside our heads (First edition). A Borzoi book. New York: Alfred A. Knopf.

Zerfass, A., Verčič, D., Nothhaft, H., \& Werder, K. P. (2018). Strategic Communication: Defining the Field and its Contribution to Research and Practice. International Journal of Strategic Communication, 12(4), 487-505. https://doi.org/10.1080/1553118X.2018.1493485 
This is an Accepted Manuscript of an article published by Taylor \& Francis in International Journal of Strategic Communication, available online:

Lischka, J. A. (2019). Strategic Communication as Discursive Institutional Work: A Critical Discourse Analysis of Mark Zuckerberg's Legitimacy Talk at the European Parliament. International Journal of Strategic Communication. Advance online publication. https://doi.org/10.1080/1553118X.2019.1613661

Zuboff, S. (2015). Big other: Surveillance capitalism and the prospects of an information civilization. Journal of Information Technology, 30(1), 75-89.

https://doi.org/10.1057/jit.2015.5

Zucker, L. G. (1987). Institutional Theories of Organization. Annual Review of Sociology, $13,443-464$.

Zuckerberg, M. (2018). Continuing our focus for 2018 to make sure the time we all spend on Facebook is time well spent... Retrieved from https://www.facebook.com/zuck/posts/10104445245963251 
This is an Accepted Manuscript of an article published by Taylor \& Francis in International Journal of Strategic Communication, available online:

Lischka, J. A. (2019). Strategic Communication as Discursive Institutional Work: A Critical Discourse Analysis of Mark Zuckerberg's Legitimacy Talk at the European Parliament. International Journal of Strategic Communication. Advance online publication. https://doi.org/10.1080/1553118X.2019.1613661

Table 1: Discursive legitimation strategies

Legitimacy Discursive Signal Discursive Narrative

Dimension

Pragmatic Corporate ability Instrumental rationalization

- Expertise

- Utility and benefits

- Positive externalities

Mythopoesis

- Company history, e.g., founding myth

Moral Ethical responsibility Moral evaluation

- Conforming to values (e.g., wellbeing, leadership, public interest, security, and success)

Substantive action

- Excusing (speech act)

- Revising practices

Cognitive Conformity Authorization

- References to law, standards, common sense etc.

Substantive action

- Formalizing/professionalizing operations

Institutional work

- Popularizing new models 
This is an Accepted Manuscript of an article published by Taylor \& Francis in International Journal of Strategic Communication, available online:

Lischka, J. A. (2019). Strategic Communication as Discursive Institutional Work: A Critical Discourse Analysis of Mark Zuckerberg's Legitimacy Talk at the European Parliament. International Journal of Strategic Communication. Advance online publication. https://doi.org/10.1080/1553118X.2019.1613661

Note. Synthesis of discursive legitimation strategies based on Kim and Rader (2010), Lawrence and Suddaby (2006), Scherer et al. (2013), Suchman (1995), and van Leeuwen and Wodak (1999). 
This is an Accepted Manuscript of an article published by Taylor \& Francis in International Journal of Strategic Communication, available online:

Lischka, J. A. (2019). Strategic Communication as Discursive Institutional Work: A Critical Discourse Analysis of Mark Zuckerberg's Legitimacy Talk at the European Parliament. International Journal of Strategic Communication. Advance online publication. https://doi.org/10.1080/1553118X.2019.1613661

Table 2: Structure of the hearing

Parts of the hearing Topics

1. Introduction of the President ofNegative externalities of Facebook for users and their the European Parliament, communication in democratic societies

ca. $7 \mathrm{~min}$

2. Opening statement of Mark

Zuckerberg,

ca. $11 \mathrm{~min}$
(1) Commitment to European values;

(2) Positive externalities of Facebook;

(3) Apology;

(4) Reference to substantive action

3. Questions of Parliament mem- Negative externalities of Facebook for users and their bers, communication in democratic societies; Processes of

ca. $40 \mathrm{~min}$

4. Testimony of Mark Zuckerberg,

ca. $23 \mathrm{~min}$ surveillance and data harvesting

(1) User-generated content with negative externalities;

(2) Election integrity;

(3) Regulation;

(4) Competition;

(5) Tax paying;

(6) EU General Data Protection Regulation (GDPR);

(7) Political bias;

(8) Wellbeing;

(9) Cambridge Analytica 
This is an Accepted Manuscript of an article published by Taylor \& Francis in International Journal of Strategic Communication, available online:

Lischka, J. A. (2019). Strategic Communication as Discursive Institutional Work: A Critical Discourse Analysis of Mark Zuckerberg's Legitimacy Talk at the European Parliament. International Journal of Strategic Communication. Advance online publication. https://doi.org/10.1080/1553118X.2019.1613661

5. Spontaneous follow-up on un- Shadow profiles; data usage across platforms; targeted answered questions,

political advertising

ca. $2 \mathrm{~min}$

6. President's closure, Zuckerberg agrees to answer the remaining questions

ca. 2 min in written format. 
This is an Accepted Manuscript of an article published by Taylor \& Francis in International Journal of Strategic Communication, available online:

Lischka, J. A. (2019). Strategic Communication as Discursive Institutional Work: A Critical Discourse Analysis of Mark Zuckerberg's Legitimacy Talk at the European Parliament. International Journal of Strategic Communication. Advance online publication. https://doi.org/10.1080/1553118X.2019.1613661

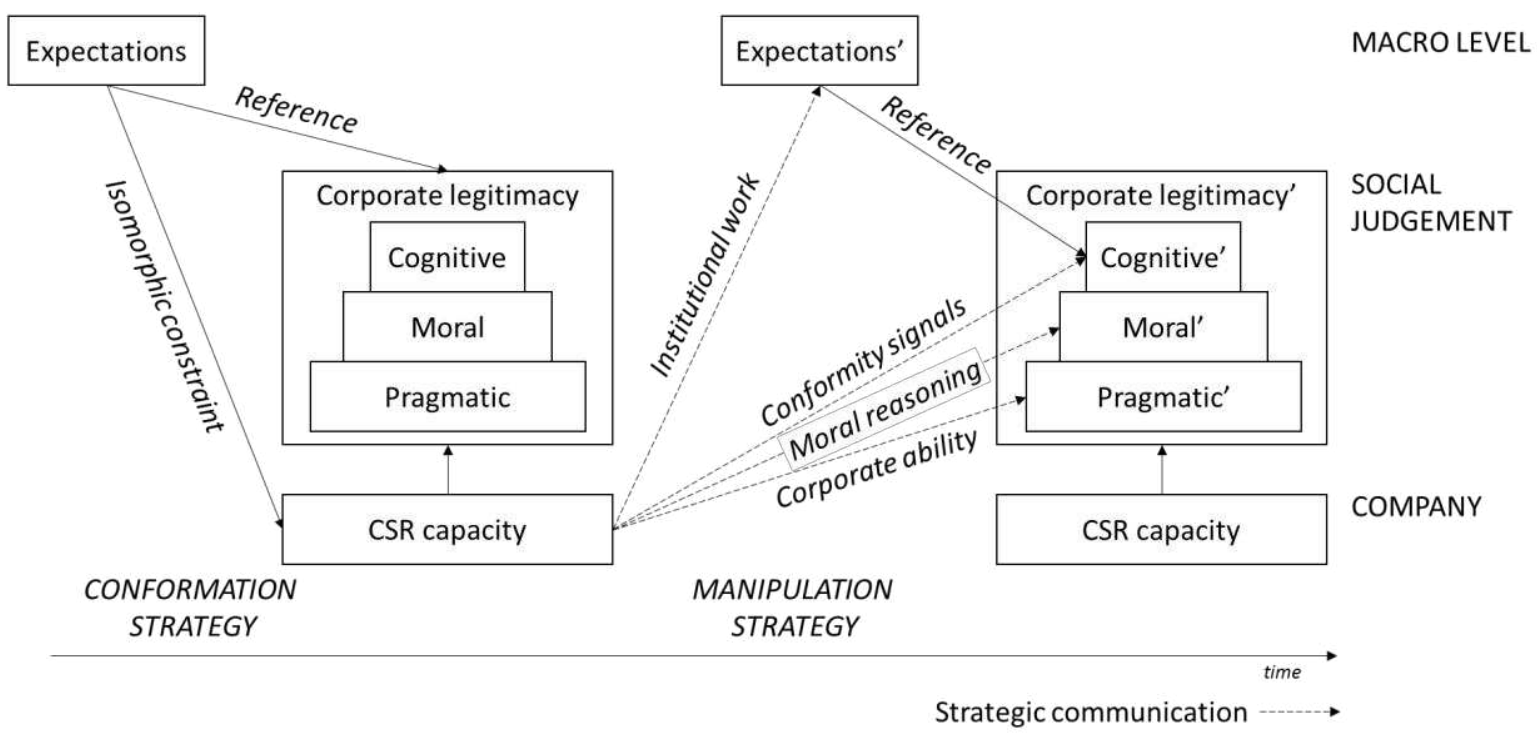

Figure 1: Strategic communication as legitimacy signal and institutional work 
This is an Accepted Manuscript of an article published by Taylor \& Francis in International Journal of Strategic Communication, available online:

Lischka, J. A. (2019). Strategic Communication as Discursive Institutional Work: A Critical Discourse Analysis of Mark Zuckerberg's Legitimacy Talk at the European Parliament. International Journal of Strategic Communication. Advance online publication. https://doi.org/10.1080/1553118X.2019.1613661

Topics

Legitimacy defense narratives

Discursive legitimacy signal

(1) User-generated conten with negative externalities

(2) Election integrity

(3) Regulation

(4) Competition

(5) Tax paying

(6) GDPR

(7) Political bias

(8) Wellbeing

(9) Cambridge Analytica
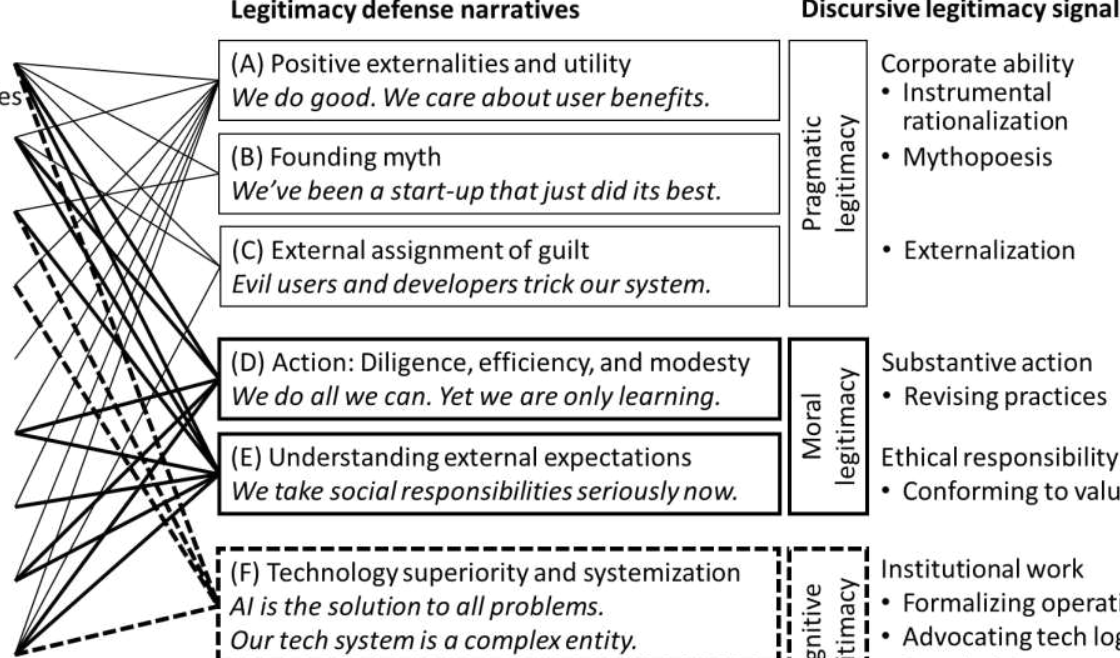

(D) Action: Diligence, efficiency, and modesty

We do all we can. Yet we are only learning.

(E) Understanding external expectations We take social responsibilities seriously now.

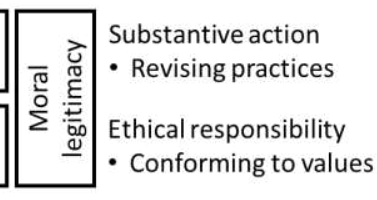

(F) Technology superiority and systemization $A$ is the solution to all problems. Our tech system is a complex entity.

- Formalizing operations Copularizing new Conclusion: Don't overregulate Al.

models

Unanswered: Shadow profiles, cross-platform Technical implementation of user data data usage, political advertising targeting commodification

Figure 2: Zuckerberg's legitimacy defense narratives 